UDC 378.147:355.233

DOI: $10.31470 / 2415-3729-2019-10-158-175$

\title{
Organizational and Pedagogical Conditions of Providing Communication Readiness for Future Engineering Officers
}

\section{Lidiia Nanivska}

Postgraduate student of the extramural form of study of the Department of Pedagogy

Khmelnytskyi Humanitarian-Pedagogical Academy

$\triangle 139$, Proskurivskoho Pidpillia Str., Khmelnitskyi, Ukraine, 29013

E-mail: lida_88@ukr.net

ORCID: 0000-0002-8922-8241

Date of receipt of the article: September 28, 2019 Article accepted for publication: December 02, 2019

Організаційно-педагогічні умови забезпечення комунікаційної готовності майбутніх офіцерів інженерних військ

\section{Лідія Леонідівна Нанівська}

аспірант заочної форми навчання кафедри педагогіки Хмельницької гуманітарно-педагогічної академії

$\triangle$ вул. Проскурівського підпілля, 139, м. Хмельницький, Україна, 29013

Дата надходження статті: 28 вересня 2019 р. Стаття прийнята до друку: 02 грудня 2019 р.

\section{Abstract}

The article considers the terms «conditions», «pedagogical conditions», «organizational and pedagogical conditions» and their interpretation by scientists in modern pedagogical education. The purpose of the article is to determine the organizational and pedagogical 
conditions of providing the communication readiness of future engineering officers to professional activity. It's been highlighted the organizational and pedagogical conditions that provide for the formation of communication readiness for foreign language activity of future officers of the engineering troops. Namely: the formation of positive motivation for mastering the components of communicative competence and values in their own self-realization; the use of innovative methods and forms, information and communication technologies in the training of the engineering officers for foreign language communication; the organization of individual work of the future officers of engineering troops with the use of information and communication technologies.

In the justification of the first condition, motivational resources that help military personnel to study English are emphasized. They include: knowledge of vocational-oriented terminology; the ability to communicate with partners from different national forces, familiarity of relevant structures and features of international documentation in the context of international cooperation; fluency in English that will allow military personnel communicate with the local population in the framework of peacekeeping operations, in which Ukraine is actively involved; an opportunity to increase the level of knowledge of a foreign language for servicemen who have successfully passed the tests at language (professional) courses abroad. Forms and methods of creation of positive motivation are defined.

To administer the second organizational and pedagogical condition, the main English study programs for the future officers are determined: Language in Use 24/7, QDictionary, FVords, EZ Memo Booster, Exerciser.

The bases for the third pedagogical condition were identified from the analysis of scientific and methodological literature. They are the aspects of the problems of individual work of cadets. Individual work means to take the responsibility for deep and strong mastering of basic knowledge, formation of skills from the studied subject which promotes the education of cognitive independence and individual activity; determines the degree of mastery of special methods of educational 
work by the students; is the basis for the formation of the need to constantly update their knowledge, readiness for self-education; is a means of forming the independence of educational cognitive activity. Much attention is paid to teaching methods.

The study used data from psychological and pedagogical sources and from scientific research. The comparative method of analysis is applied.

Key words: conditions, organizational and pedagogical conditions, cadets, communicative competence, information and communication technologies.

\section{References}

1. Babanskiy, Yu.K. (1982). Problemy povysheniya effektivnosti pedagogicheskih issledovaniy: didakticheskiy aspekt [Problems of increasing the pedagogical research effectiveness: didactic aspect]: Moskva: Pedagogika [in Russian].

2. Borodina, H.I. (2011). Vykorystannia problemnykh zavdan dlia formuvannia movnoi kompetentsii u navchanni anhliiskoi movy studentiv nemovnykh spetsialnostei [The use of problematic tasks for the formation of language competence in teaching non-philology students English]. Inozemni movy - Foreign languages, 1, 36-39 [in Ukrainian].

3. Borodina, H.I. (2013). Shchodo problemy formuvannia stiikoi motyvatsii do vyvchennia inozemnoi movy u studentiv inzhenernykh spetsialnostei. [On the problem of formation of sustainable motivation for engineering students to learn a foreign language] Vykladannia mov u vyshchykh navchalnykh zakladakh osvity na suchasnomu etapi. Mizhpredmetni zviazky - Language teaching at higher education institutions at the present stage, 22, 59-67 [in Ukrainian].

4. Busel, V.T. (Ed.). (2005). Velykyi tlumachnyi slovnyk suchasnoi ukrainskoi movy (z dod. i dopov.) [A great explanatory dictionary of modern Ukrainian]. Irpin: VTF «Perun» [in Ukrainian].

5. Hrytsiuk, L.K. (2012). Orhanizatsiia samostiinoi roboty studentiv u navchalnomu protsesi vyshchoho navchalnoho zakladu. 
[Organization of students independent work in the educational process of higher education institution]. Visnyk Volynskoho natsionalnoho universytetu. Imeni L. Ukrainky - Bulletin of the Volyn National University. The name of L. Ukrainka, 9 - 14 [in Ukrainian].

6. Dubinina, G.K. (2011). Uchebno-metodicheskoe obespechenie bazovogo kursa podgotovki bakalavrov po angliyskomu yazyku. [Educational and methodological support for the basic course of preparation of bachelors in English] Vestnik MGLU - Bulletin of MSLU, 12 (646), 37-42 [in Russian].

7. Zubko, A.M. (2002). Orhanizatsiino-pedahohichni umovy udoskonalennia navchalnoho protsesu $\mathrm{v}$ systemi pidvyshchennia kvalifikatsii pedahohichnykh kadriv [Organizational and pedagogical conditions for improving the educational process in the system of pedagogical staff training] Extended abstract of candidate's thesis. Kyiv [in Ukrainian].

8. Kodzhaspirova, G.M., Kodzhaspirov, A.Yu. (2005). Slovar po pedagogike [Dictionary of Pedagogy]. Moskva: IKTs «MarT»; Rostov n/D: Izdatelskiy tsentr «MarT» [in Russian].

9. Lerner, Yu.I. (2014). Povyishenie kachestva ekonomicheskogo obrazovaniya $v$ Ukraini [Improving the quality of economic education in Ukraine]. Harkiv [in Russian].

10. Mychkovska, V.R (2001). Do pytan orhanizatsii samostiinoi roboty na pochatkovomu etapi vyvchennia inozemnoi movy. [On the issues of organizing independent work at the initial stage of learning a foreign language]. Materialy mizhvuzivskoi konferentsii-Proceedings of the Intercollegiate Conference, Khmelnytskyi: Vyd-vo Natsionalnoi akademii PVU, 13(2), 176-184. [in Ukrainian].

11. Rodyhina, I.V. (2008). Kompetentnisno oriientovanyi pidkhid do navchannia [Competency-oriented approach to learning]. Kharkiv [in Ukrainian].

12. Chyzhevskyi, B.H. (1996). Orhanizatsiino-pedahohichni umovy stanovlennia litseiv $v$ Ukraini [Organizational and pedagogical conditions of lyceums formation in Ukraine]. Instytut pedahohiky APN Ukrainy [in Ukrainian]. 
13. Shcherba, D.V. (2015). Osoblyvosti vporiadkuvannia ta perekladu terminolohii verbalizovanykh termino-kontseptiv (na prykladi terminokontseptu «Kompiuterna bezpeka») [Features of organizing and translating the terminology of verbalized term concepts (for example, the «Computer Security» term concept)]. Visnyk Zhytomyrskoho derzhavnoho universytetu imeni Ivana Franka - Bulletin of Zhytomyr Ivan Franko State University, 2, 227-231. Retrieved from http://nbuv. gov.ua/UJRN/VZhDU_2015_2_47 [in Ukrainian].

14. Iahupov, V.V. (2002). Pedahohika [Pedagogy]: navch. posib. Kyiv,. 560 s. Retrieved from: http://eduknigi.com/ped_view.php?id=36 [in Ukrainian].

\section{Вступ}

У період розбудови української держави докорінно відбуваються ситуаційні зміни в системі освіти, виникає потреба в ii демократичному розвитку та вдосконаленні в тому числі й військової освіти. Основні напрями радикальних змін в освіті передбачені Державною національною програмою «Освіта» («Україна XXI сторіччя»), Законах України «Про освіту» i «Про вищу освіту», Національній доктрині розвитку освіти та Національній програмі інформатизації України, наказі МО України від 20.07.2015 року № 346 «Про затвердження Положення про особливості організації освітнього процесу у вищих військових навчальних закладах Міністерства оборони України та військових навчальних підрозділах вищих навчальних закладів України». У цих документах звертається увага на необхідності розвитку освіти на основі сучасних педагогічних концепцій, запровадження у освітній процес ЗВО і ВВНЗ особистісно орієнтованих і діяльнісних педагогічних технологій, зокрема інформаційно-телекомунікаційних технологій.

Проблема формування i удосконалення професійної компетентності майбутніх офіцерів детально розглядалася в дослідженнях військових педагогів: Г. Артюшин, В. Баратюк, С. Дяков, О. Торічний, О. Ставицький, В. Ягупов. Окремі 
складові професійної компетентності вивчали Ю. Мельничук, А. Корехов, В. Назаренко, М. Нещадим. Методологічні і педагогічні підходи щодо підвищення якості професійної підготовки майбутніх офіцерів офіцерів у закладах вищої освіти і вищих військових навчальних закладах розглянуто в працях І. Грязнова, О. Діденка, Я. Зорія, Д. Іщенка, О. Тогочинського, В. Ягупова та інших. Різні види умов формування інформаційної культури у майбутніх офіцерів розглянуто низкою науковців: педагогічні i організаційно-педагогічні умови формування інформаційної культури майбутніх офіцерів-прикордонників досліджено в працях А. Білоруса, питання підготовки майбутніх офіцерів-прикордонників до застосування інформаційнотелекомунікаційних технологій у забезпеченні системи зв'язку прикордонних підрозділів висвітлено в працях О. Блажука, проблему особливостей формування інформаційної культури офіцерів-прикордонників при навчанні іноземної мови детально подано в статтях І. Блощинського.

Але недостатньо розроблено питання щодо формування комунікаційної готовності майбутніх офіцерів інженерних військ. Тому метою статті є визначити організаційно-педагогічні умови забезпечення комунікаційної готовності майбутніх офіцерів інженерних військ до професійної діяльності.

\section{Матеріал і методи дослідження}

У проведеному дослідженні було використано дані психологопедагогічних джерел та дані проведених наукових досліджень щодо визначення організаційно-педагогічних умов забезпечення комунікаційної готовності майбутніх офіцерів інженерних військ.

Застосовано порівняльний метод аналізу. Це дало можливість виокремити специфічні організаційно-педагогічні умови для забезпечення комунікаційної готовності майбутніх офіцерів інженерних військ.

\section{Результати та їх обговорення}

Аналіз психолого-педагогічної літератури дозволив виділити визначення поняттям «умови» $\mathrm{i}$ «педагогічні умови». 
Умови це:

- обставини, які обумовлюють появу розвиток того чи іншого процесу (Бабанский, 1982);

- сукупність взаємозалежних і взаємообумовлених обставин процесу діяльності (Родигіна, 2008);

- єдність об'єктивного і суб'єктивного, внутрішнього і зовнішнього, сутності і явища (Ягупов, 2002);

- сукупність внутрішніх і зовнішніх чинників, які взаємопов'язані між собою, чим забезпечується ефективність навчального процесу, що сприяє функціонуванню психологопедагогічних критеріїв оптимальності (Лернер, 2014).

У «Великому тлумачному словнику сучасної української мови» подано ще одне поняття «умови»: це «правила, які існують або встановлені в тій чи іншій галузі життя, діяльності, які забезпечують нормальну роботу чого-небудь» (Великий тлумачний словник сучасної української мови, 2005).

Оскільки ми розглядаємо організаційно-педагогічні умови підготовки до іншомовного спілкування майбутніх офіцерів інженерних військ, нас зацікавила лексема «організація», яка визначається як сукупність змісту і засобів для координації дій окремих елементів системи (Великий тлумачний словник сучасної української мови, 2005).

Процес підготовки майбутніх офіцерів базується на діяльнісному підході, тому необхідним $є$ словосполучення «організація діяльності», яке знайшли в словнику з педагогіки, де він визначається як процес об'єднання людей і засобів для досягнення поставленої мети (Коджаспирова\&Коджаспиров, 2005).

Тобто, «організувати» означає: 1) зосередити, мобілізувати, спрямовувати; 2) чітко налагодити, належно впорядковувати щонебудь (Великий тлумачний словник сучасної української мови, 2005).

Таким чином, організаційно-педагогічні умови - це фактори, зорієнтовані на організацію навчання у вищій школі. До цих факторів відносимо: впровадження педагогічних технологій, 
заходів, методів, прийомів, вимог у освітній процес. У процесі дослідження запропоновано авторське тлумачення поняття «організаційно-педагогічних умов підготовки майбутніх військових інженерів до іншомовної професійної комунікації» як сукупності зовнішніх i внутрішніх факторів (педагогічних технологій, засобів, методів та організаційних форм навчання, що забезпечують готовності майбутніх офіцерів до іншомовної комунікації.

При визначенні організаційно-педагогічних умов ми використали праці Б. Чижевський, який вказував, що організаційнопедагогічні умови повинні враховувати функціональну залежність між компонентами педагогічного процесу i об'єктами (Чижевський, 1996). За А. Зубковим (Зубко, 2002) класифікація організаційно-педагогічних умов грунтується на матеріальнотехнічному, навчально-методичному забезпеченні освітнього процесу. Проаналізувавши подання Б. Чижевського, ми вважаємо, що організаційно-педагогічні умови є сукупністю факторів, обставин, що сприяють позитивній взаємодії об’ єктів і явищ освітнього процесу, що забезпечує його результативність.

На основі аналізу психолого-педагогічної літератури ми виділили такі організаційно-педагогічні умови формування готовності майбутніх військових інженерів до іншомовної комунікації: формування позитивної мотивації до набуття комунікативної компетентності i иіннісних орієнтацій при самореалізації; використання інноваційних методів, форм та інформаційно-комунікаційних технологій у підготовці офіцерів інженерних військ до іншомовної комунікаиїі; організація самостійної роботи майбутніх офіцеерів інженерних військ з використанням інформаційно-комунікаційних технологій.

Розглядаючи можливі приклади педагогічних умов, ми обирали ті, які повинні були підвищити якість підготовки фахівців. За нашим задумом вони повинні стосуватися як організації освітнього процесу, так і ефективності підготовки. Тому серед видів умов було обрано організаційно-педагогічні. Перша організаційно- 
педагогічна умова - формування позитивної мотивації до набуття комунікативної компетентності і цүіннісних орієнтацій при самореалізаиї

Одним із важливих факторів якісної підготовки фахівців $є$ мотивація до майбутньої професії. Тому іiі формування є достатньо складним і визначальним процесом, який можливо реалізувати при сумісній діяльності викладача і курсанта. Такий процес взаємодії потребує значних зусиль викладача і курсанта. Взаємодія в системі викладач - курсант при навчанні іноземній мові вимагає від викладача знань та умінь використання в освітньому процесі інноваційних методів і методик навчання, прийомів та спеціальної навчальної техніки. А від курсанта має бути бажання опанувати ці знання.

Вивчаючи це питання, ми дійшли висновку, що серед сучасних методів і методик навчання, потрібно обирати ті, які будуть сприяти мотивації. 3 цією метою ми розробили завдання, виконання яких забезпечує: розвиток у курсантів бажання практичного вживання іноземної мови, створюючи атмосферу, в якій вони будуть почувати себе вільно і комфортно; заохочення курсантів до вивчення іноземної мови; стимулювання інтересів курсантів у вивченні іноземної мови та набуття вмінь застосування пї на практиці; активізацію мовних, когнітивних і творчих здібностей курсантів; створення ситуацій, в яких центральною фігурою у навчальному процесі $є$ курсант, його особистість і інтереси; використання групової, індивідуальної та колективної форми роботу в аудиторії, що стимулює в курсантів активність, їхню самостійність та творчість.

До мотиваційних ресурсів, що сприяють вивченню англійської мови майбутніми офіцерами, які ми використовували у своєму дослідженні, було віднесено: знання професійно-орієнтованої термінології, яка має певну специфіку (Щерба, 2015); можливість спілкуватися 3 військовими партнерами різних національних сил; вільне володіння англійською мовою, що дозволяє офіцерам спілкуватися 3 місцевим населенням в рамках миротворчих 
операцій, в яких Україна приймає активну участь; можливість підвищити рівень знань іноземної мови для військовослужбовців, які успішно склали тести на мовних (фахових) курсах за кордоном.

Ще одним шляхом мотивації є забезпечення автоматизації мовлення. Недостатній розвиток автоматизму мовлення заважає швидкому усному спілкуванню, що вказує на брак мовленнєвої практики. Продуктивною мовленнєвою практикою вважається та, котра сприяє концентрації уваги курсанта на об’єкті, який вивчається, не дотримуючись правил граматики. 3 цією метою ми використовуємо завдання, що потребують уваги і спрямовані на екстралінгвістичну мету.

Наші дослідження показала, що такі комунікативні завдання сприяють формуванню навичок вільного використання мови та розвивають мовний автоматизм.

У дослідженні нами був використаний потенціал ігрових технологій щодо формування комунікативної компетентності, оскільки при їх проведенні створюється групова відповідальність за результати гри, що об'єднує курсантів, які мають спільні інтереси - перемогти. Це надає можливість викладачу виносити на розгляд групи більш складні ситуації, в яких мова $є$ одним із засобів розв'язання ситуацій або передачі інформації. Ігри застосовуємо 3 метою закріплення лексичних елементів або граматики. Наш досвід практичної діяльності показав, що одним з головних призначень ігор є забезпечення курсантам можливості для вільного спілкування (Бородіна, 2013). У який спосіб - це продумує викладач. Ми враховували, що проведення гри повинно сприяти розвитку навичок мовленнєвої діяльності, що зробить гру захоплюючою, а це забезпечить високий рівень мотивації. Застосування гри дозволило швидко перейти до власне комунікативної діяльності при навчанні усного спілкування. Найбільш ефективними виявилися такі види ігор: ділова гра, імітаційне моделювання, рольова гра, стимуляційні і імітаційна гра.

Тому ми вважаємо, що ігри є позитивним мотиваційним фактором при навчанні іноземної мови курсантів ВВНЗ. 
Другою організаційно-педагогічною умовою було обрано використання інноваційних методів, форм та інформаиійнокомунікачійних технологій у підготовиі офіцерів інженерних військ до іншомовної комунікаиії.

Для реалізації цієї умови значну увагу ми приділили методам навчання. Серед них виділяли інтерактивні, які найбільше впливають на розкриття творчого потенціалу курсанта. Наші дослідження показали, що позитивні результати одержували при застосуванні ділових і рольових ігор 3 використанням навчальних стендів, навчальних тренінгів які допомагали розв'язати нестандартні ситуації, створення портфоліо. Велику увагу приділяли проблемному методу, адже при цьому виправлення помилок проводиться не індивідуально, а групою. Висловлення багатьох, можливо різних, думок сприяє розширенню діапазону розв'язання ситуації, що закладена в сценарій гри. Напружений темп спільної праці, необхідність брати в ній участь не дають можливості відволікатися на інші питання, що не стосуються проблеми. Тому необхідно детально розробляти сценарії гри, продумуючи всі особливості проблеми. Формування мовної компетенції є однією з складових процесу навчання іноземній мові. Наші дослідження показали, що самою складною ланкою у цьому процесі є засвоєння граматики іноземної мови. Комплекс проблемних завдань для формування комунікативної компетентності мотивує курсантів до вивчення граматики та засвоєння граматичних правил (Бородіна, 2011). Тобто, друга умова пов'язана і доповнює реалізацію першої умови.

Використання IКT у педагогічній діяльності викладача іноземної мови $€$ пріоритетним, оскільки це допомагає перетворити навчання іноземної мови у творчий процес і багато курсантів починають розкриватися, перестають комплексувати і виявляють інтерес до вивчення іноземної мови за професійним спрямуванням.

Для реалізації цієї організаційно-педагогічної умови пропонуються програми, що забезпечують вивчення англійської мови майбутніми офіцерами. 
1. Language in Use 24/7. Програму розроблено на основі однойменної серії підручників видавництва Cambridge University Press. Три рівні програми Beginner (Початковий), Pre-Intermediate (Базовий), Intermediate (Середній) відповідають стандартам Загальної європейської системи вивчення мов (рівні А1/A2, В1/B2)

2. Програма використовує технологію, яка дозволяє перекладати слова та словосполучення простим наведенням курсору миші на них. Словникова база містить більш ніж 50000 слів та словосполучень. Забезпечується можливість додавання своїх слів і внесення змін в ті, що існують в програмі.

3. FVords. Програма містить тести, словники до оригіналу, паралельні тексти, режим суфлера, пошук, друк, статистика та ін. Пропонує п’ять підходів до вивчення матеріалу: турнір, курс, звичайний, книга та суфлер.

4. EZ Memo Booster. Програма допомагає при регулярних заняттях швидко поповнити словниковий запас.

5. Exerciser. Програма задає вправи декількох типів в різних варіаціях - зміна форми слів або речень (наприклад, поставити в негативну форму), пошук помилок в тексті, підставлення варіантів, заповнення пропусків, пошук відповідностей. Програма забезпечує перевірку вправ.

Використання новітніх інформаційних технологій у процесі вивчення іноземних мов у ВВНЗ підвищує ефективність формування всіх аспектів іншомовної комунікативної компетенції. Це має певні переваги, а саме: необмежена кількість часу, повна неупередженість, об'єктивність і безмежне терпіння.

Вивчаючи це питання, ми дійшли висновку, що впроваджуючи сучасні методи навчання, потрібно враховувати такі завдання: розвивати у курсантів бажання практичного вживання іноземної мови, створюючи атмосферу, в якій вони будуть почувати себе вільно і комфортно; заохочувати курсантів до вивчення іноземної мови; стимулювати інтереси курсантів у вивченні іноземної мови та набуття вмінь застосування іiі на практиці; активізувати мовні, когнітивні і творчі здібності курсантів; створювати ситуації, в 
яких центральною фігурою у навчальному процесі є курсант, його особистість і інтереси; використовувати групову, індивідуальну та колективну форми роботу в аудиторії, що стимулює в курсантів активність, їхню самостійність та творчість. Аналіз психологопедагогічної літератури і власні дослідження показали, що застосування проблемного методу у іншомовній підготовці курсантів ВВНЗ $є$ найбільш дієвим методом формування мотивації до навчально-пізнавальної діяльності курсантів. Аналіз причин ефективності проблемного методу показав, що це пояснюється підвищенням власної відповідальності, прийняття самостійних рішень і потреба відповідати за результати, що мотивує необхідність у розширенні діапазону знань, а відповідно стимулює активність у самопідготовці. Підтвердження наших висновків ми знайшли в працях науковців (Дубинина, 2011). Підготовка майбутніх офіцерів в Академії сухопутних військ імені гетьмана Петра Сагайдачного здійснюється реалізацією саме таких програм.

В рамках розробленої концепції використовують навчальні комп'ютерні програми, що дозволяє реалізувати мовну концепцію за всіма напрямами. До прикладу Longman English Interactive-1-3 - це чотирирівнева програма формування інтегрованих навичок, орієнтована на використання відео. Студенти працюють із сучасними та захоплюючими відео, аудіо, анімацією та великим набором практичних занять для розвитку основних навичок.

Організачія самостійної роботи майбутніх офіцерів інженерних військ з використанням інформаційно-комунікаційних технологій.

Діяльність курсантів організує викладач, а курсанти іiі здійснюють. Тому самостійна робота завершує задачі всіх видів навчальної роботи і сприяє: поглибленню та розширенню знань; формуванню інтересу до професійної діяльності; оволодінню прийомами процесу пізнання; розвитку здібностей.

Досліджено, що самостійна робота є резервом підвищення ефективності підготовки майбутніх офіцерів. Під самостійною навчальної роботою розуміємо планову роботу, яка виконується 
за індивідуальними завданнями, але в присутності викладача (Грицюк\&Сірук, 2012).

Отже, аналіз наукової та методичної психолого-педагогічної літератури дозволяє виділити роль самостійної роботи курсантів: засіб глибокого та міцного засвоєння основних знань, формування умінь i навичок 3 вивченого предмета; сприяє вихованню пізнавальної самостійності та активності особистості; основа для формування потреби до постійного поповнення своїх знань, готовності до самоосвіти; засіб формування самостійності навчально-пізнавальної діяльності (Мичковська, 2001).

Одним із методів організації самостійної роботи курсантів ми обрали - метод творчого пошуку (дослідження). Найчастіше метод застосовуємо при виконанні творчих завдань, які пропонує викладач. Для їх виконання використовуємо семінарські, практичні заняття. Такий підхід забезпечує і самостійність і консультування викладача.

\section{Висновок}

Таким чином визначено організаційно-педагогічні умови: формування позитивної мотивації до оволодіння складниками комунікативної компетентності і ціннісних орієнтирів у власній самореалізації; використання інноваційних методів і форм та IKT у процесі підготовки офіцерів інженерних військ до іншомовної комунікації; організація самостійної роботи майбутніх офіцерів інженерних військ 3 використанням інформаційно-комунікаційних технологій. В обгрунтуванні першої умови виділено мотиваційні ресурси, що сприяють вивченню англійської мови військовослужбовцями. Визначено форми і методи формування позитивної мотивації. Для забезпечення другої організаційнопедагогічної умови виділено основні програми що забезпечують вивчення англійської мови майбутніми офіцерами: Language in Use 24/7, QDictionary, FVords, EZ Memo Booster, Exerciser. 3 аналізу наукової та методичної психолого-педагогічної літератури виділили аспекти проблеми самостійної роботи курсантів, що покладено в основу реалізації третьої педагогічної умови. 


\section{Література}

1. Бабанский Ю.К. Проблемы повышения эффективности педагогических исследований: дидактический аспект: монография Москва : Педагогика, 1982. 192 с.

2. Бородіна Г.І. Використання проблемних завдань для формування мовної компетенції у навчанні англійської мови студентів немовних спеціальностей. Іноземні мови. Київ: Ленвіт, 2011. №1. C. 36-39.

3. Бородіна Г.I. Щодо проблеми формування стійкої мотивації до вивчення іноземної мови у студентів інженерних спеціальностей. Викладання мов у вищих навчальних закладах освіти на сучасному етапі. Міжпредметні зв'язки. Харків: видво ХНУ, 2013. №22. С. 59-67.

4. Великий тлумачний словник сучасної украӥнської мови (з дод. $\mathrm{i}$ допов.) / упоряд. і голов. ред. В.Т. Бусел. Ірпінь: ВТФ «Перун», 2005. $1728 \mathrm{c}$.

5. Грицюк Л.К., Сірук М.В. Організація самостійної роботи студентів у навчальному процесі вищого навчального закладу. Вісник Волинського національного університету. Імені Л. Українки. Луцьк. 2012. C. 9-14.

6. Дубинина Г.К. Учебно-методическое обеспечение базового курса подготовки бакалавров по английскому языку. Вестник МГЛУ. Вып. 12 (646). М., 2011. С.37-42.

7. Зубко А.M. Організаційно-педагогічні умови удосконалення навчального процесу в системі підвищення кваліфікації педагогічних кадрів : автореф. дис. на здобуття наук. ступеня канд. пед. наук : спец. - 13.00.04 «Теорія і методика професійної освіти» Київ, 2002. 22 с.

8. Коджаспирова Г.М., Коджаспиров А.Ю. Словарь по педагогике. Москва: ИКЦ «МарТ»; Ростов н/Д: Издательский центр «МарТ», 2005. $448 \mathrm{c}$.

9. Лернер Ю.И. Повышение качества экономического образования в Украине: монография. Харків, 2014. 339 с.

10. Мичковська В.Р. До питань організації самостійної ро- 
боти на початковому етапі вивчення іноземної мови. Матеріали міжвузівської конферениії. Збірник наукових праць №13, частина 2 (Спеціальний випуск). Хмельницький: Вид-во Національної академії ПВУ, 2001. С. 176-184.

11. Родигіна I.В. Компетентнісно орієнтований підхід до навчання. Харків, 2008. 112 с.

12. Чижевський Б.Г. Організаційно-педагогічні умови становлення ліцеїв в Україні. Інститут педагогіки АПН України, 1996. 249 с.

13. Щерба Д.В. Особливості впорядкування та перекладу термінології вербалізованих терміно-концептів (на прикладі терміноконцепту «Комп'ютерна безпека») Вісник Житомирського державного університету імені Івана Франка. 2015. Вип. 2. С. 227231. URL: http://nbuv.gov.ua/UJRN/VZhDU_2015_2_47 (дата звернення 28.09.2019)

14. Ягупов В.В. Педагогіка: навч. посіб. Київ, 2002. 560 с. URL: http://eduknigi.com/ped_view.php?id=36 (дата звернення: 20.09.2019).

\section{Нанівська Л.Л.}

\section{Організаційно-педагогічні умови забезпечення комунікаційної готовності майбутніх офіцерів інженерних військ}

У статті розглянуто поняття «умови», «педагогічні умови», організаційно-педагогічні умови» та їх трактування науковцями в сучасній педагогічній освіті. Визначено організаційно-педагогічні умови: формування позитивної мотивації до оволодіння складниками комунікативної компетентності і ціннісних орієнтирів у власній самореалізації; використання інноваційних методів і форм та IКТ у процесі підготовки офіцерів інженерних військ до іншомовної комунікації; організація самостійної роботи майбутніх офіцерів інженерних військ 3 використанням інформаційнокомунікаційних технологій. В обгрунтуванні першої умови виділено мотиваційні ресурси, що сприяють вивченню англійської 
мови військовослужбовцями. Визначено форми і методи формування позитивної мотивації. Для забезпечення другої організаційнопедагогічної умови виділено основні програми що забезпечують вивчення англійської мови майбутніми офіцерами: Language in Use 24/7, QDictionary, FVords, EZ Memo Booster, Exerciser. 3 аналізу наукової та методичної психолого-педагогічної літератури виділили аспекти проблеми самостійної роботи курсантів, що покладено в основу реалізації третьої педагогічної умови.

Ключові слова: умови, організаційно-педагогічні умови, курсанти, комунікативна компетентність, інформаційно-комунікаційні технології.

\section{Нанивськая Л.Л.}

\section{Организационно-педагогические условия обеспечения комму- никационной готовности будущих офицеров инженерных войск}

В статье рассмотрено понятие «условия», «педагогические условия», организационно-педагогические условия» и их трактовка учеными в современной педагогической образовании. Определены организационно-педагогические условия: формирование положительной мотивации к овладению частями коммуникативной компетентности и ценностных ориентиров в собственной самореализации; использование инновационных методов и форм и ИКТ в процессе подготовки офицеров инженерных войск к иноязычной коммуникации; организация самостоятельной работы будущих офицеров инженерных войск с использованием информационнокоммуникационных технологий. В обосновании первого условия выделено мотивационные ресурсы, способствующие изучению английского языка военнослужащими. Определены формы и методы формирования положительной мотивации. Для обеспечения второй организационно-педагогического условия выделены основные программы, которые обеспечивают изучение английского 
языка будущими офицерами: Language иn Use 24/7, QDисtиonary, FVords, EZ Memo Booster, Exercиser. Из анализа научной и методической психолого-педагогической литературы выделили аспекты проблемы самостоятельной работы курсантов, что положено в основу реализации третьего педагогического условия.

Ключевые слова: условия, организационно-педагогические условия, курсанты, коммуникативная компетентность, информационно-коммуникационные технологии. 